\title{
Sediaan Nanopartikel Alginat Ekstrak Etanol Daun Sirsak (Annona muricata Linn) Memiliki Efek Antikanker pada Kultur Sel Kanker Paru (HTB183)
}

\author{
Neng Resa Aulia Tulloh*, Yuke Andriane \\ Prodi Pendidikan Kedokteran, Fakultas Kedokteran, Universitas Islam \\ Bandung, Indonesia. \\ *auliatulloh@gmail.com, andrianeyuke@yahoo.com
}

\begin{abstract}
Introduction: Lung cancer is the second most common cancer in the world with the highest mortality rate. Chemotherapy is a method that has a high modality in the management of lung cancer. The disadvantage of chemotherapy is that it has a high level of resistance and side effects. One strategy to overcome these deficiencies in the development of phytopharmaceuticals. The purpose of this study was to examine the anticancer effect of alginate nanoparticles of soursop leaf ethanol extract (NPS) and its combination on HTB183 lung cancer cell culture. Methods: This research is a pure experimental study in vitro on HTB183 lung cancer cell culture which was carried out at the UGM Laboratory in March-December. Toxicity test was carried out using the MTT method to obtain the ICvalue50 and analyzed using probit regression calculation using software SPSS. Results: The results of this study showed that the IC50 alginate nanoparticles of soursop leaf ethanol extract on lung cancer cell culture were 31,261 ( \pm 4.4$) \mathrm{g} / \mathrm{mL}$. Conclusion: Alginate nanoparticles from soursop leaf ethanol extract had a moderate anticancer effect on HTB183 lung cancer cell culture. The anticancer effect of soursop leaf preparations is caused by alginate nanoparticles that can bind the content of soursop leaf extract stably.
\end{abstract}

Keywords: Anticancer, Lung Cancer, Nanoparticles, Soursop Leaf.

\begin{abstract}
Abstrak. Pendahuluan: Kanker paru merupakan kanker ke dua paling sering terjadi di dunia dengan angka kematian tertinggi. Kemoterapi menjadi salah satu metode pengobatan yang memiliki modalitas tinggi dalam penatalaksanaan kanker paru. Kekurangan dari kemoterapi adalah tingkat resistensi dan efek samping yang tinggi. Salah satu strategi untuk mengatasi kekurangan tersebut dengan mengembangkan obat antikanker bahan alam. Tujuan penelitian ini adalah menguji efek antikanker nanopartikel alginat ekstrak etanol daun sirsak (NPS) dan kombinasinya pada kultur sel kanker paru HTB183. Metode: Penelitian ini merupakan penelitian eksperimental murni in vitro pada sel kultur kanker paru HTB183 yang dilaksanakan di Laboratorium UGM pada bulan Maret-Desember. Uji toksisitas dilakukan menggunakan metode MTT untuk mendapatkan nilai IC50 dan dianalisis menggunakan penghitungan regresi probit melalui software SPSS. Hasil: Hasil penelitian ini menunjukkan IC50 nanopartikel alginat ekstrak etanol daun sirsak terhadap kultur sel kanker paru sebesar 31,261 $( \pm 4,4) \mu \mathrm{g} / \mathrm{mL}$. Simpulan: nanopartikel alginat ekstrak etanol daun sirsak memiliki efek antikanker sedang pada kultur sel kanker paru HTB183. Efek antikanker sediaan daun sirsak disebabkan oleh nanopartikel alginate dapat mengikat kandungan ekstrak daun sirsak secara stabil.
\end{abstract}

Kata Kunci: Antikanker, Daun Sirsak, Kanker Paru, Nanopartikel. 


\section{A. Pendahuluan}

Menurut American Cancer Society (ACS) pada tahun 2021 kanker paru memiliki insidensi terbanyak kedua dengan angka kematian tertinggi di dunia. ${ }^{1}$ Penyebab kanker paru diklasifikasikan menjadi dapat dirubah dan tidak dapat dirubah, penyebab yang dapat dirubah terdiri dari rokok, radon, asbestos, silika, dan yang lainnya. Sedangkan penyebab yang tidak dapat dirubah terdiri dari genetik, terapi radiasi sebelumnya, dan polusi udara. ${ }^{2}$ Interaksi berbagai faktor tersebut dalam rentang waktu yang lama akan menginduksi terjadinya mutasi pada berbagai gen seperti epidermal growth factor receptor (EGFR) dan KRAS sehingga menyebabkan terbentuknya sel kanker yang tidak terkontrol. ${ }^{3}$

Tatalaksana kanker paru terdiri dari pembedahan, kemoterapi dan radioterapi. ${ }^{4}$ Kemoterapi menjadi metode pengobatan yang paling banyak digunakan karena dapat diaplikasikan pada berbagai stadium bahkan dapat digunakan sebagai terapi paliatif. ${ }^{5}$ Meskipun kemoterapi efektif dan memiliki modalitas tinggi akan tetapi resistensi obat yang tinggi dengan efek samping yang luas menjadi kekurangan kemoterapi, sehingga pemengembangan faramakologi terus dilakukan untuk menemukan obat antikanker yang lebih baik. ${ }^{4}$

Strategi yang banyak dilakukan dan terus dieksplorasi sebagai langkah untuk mengatasi kekurangan kemoterapi adalah pengembangan fitofarmaka. Daun sirsak menjadi salah satu bahan alam yang banyak diteliti karena memiliki efek antikanker. Berbagai senyawa yang terkandung di dalam daun sirsak seperti flavonoid, annonaceous acetogenin (AGE), dan phenolic acid terbukti menjadi subtansi yang mampu menghambat proliferasi sel dan meningkatkan apoptosis sel. ${ }^{6}$ Untuk memisahkan senyawa yang terkandung di dalam daun sirsak maka diperlukan proses ekstraksi. ${ }^{7}$ Pada proses ekstraksi membutuhkan suatu pelarut, etanol menjadi salah satu pelarut yang banyak digunakan karena memiliki kepolaran yang sama dengan senyawa aktif di dalam daun sirsak. ${ }^{8}$

Pengembangan ekstrak etanol daun sirsak dalam bentuk nanopartikel diharapkan mampu meningkatkan efek senyawa aktif daun sirsak. Nanopartikel memiliki keunggulan permeabilitas membran yang tinggi karena ukurannya yang sangat kecil $(1-100 \mathrm{~nm})$, selain itu stabilitas metabolic yang tinggi, dan bioavailabilitas yang lebih besar. ${ }^{9}$ Nanomaterial yang banyak digunakan dalam proses pembuatan nanopartikel adalah alginat. Alginat merupakan nanomaterial polimer yang memiliki viskositas yang baik dan stabilitas yang tinggi. ${ }^{10}$ Tujuan penelitian ini untuk menguji efek antikanker nanopartikel alginat ekstrak etanol daun sirsak (Annona muricata L.) terhadap kultur sel kanker paru HTB183.

\section{B. Metodologi Penelitian}

Penelitian ini merupakan penelitian eksperimental murni in vitro terhadap kultur sel kanker paru HTB183 menggunakan rancangan randomize posttest only control grup design. Sel HTB183 diacak dan dimasukkan ke dalam kelompok eksperimen dan kontrol. Pengujian antikanker dilakukan di Laboratorium Parasitologi Fakultas Kedokteran Universitas Gadjah Mada. Penelitian dilaksanakan pada bulan Maret-Desember.

Proses penelitan diawali dengan mengeringkan daun sirsak dengan cara dijemur. Kemudian daun sirsak yang telah kering ditumbuk dan dibuat serbuk halus setelah itu dimaserasi menggunakan pelarut etanol 96\%, diaduk, didiamkan selama $2 \times 24$ jam, selanjutnya disaring. Filtrat diuapkan dengan vacuum rotary evaporator dalam waterbath dengan suhu $75^{\circ}$. Ekstrak kental yang dihasilkan dituang dalam cawan porselin, selanjutnya dipanaskan dengan waterbath suhu $75^{\circ} \mathrm{C}$ sambil terus diaduk dan menghasilkan ekstrak etanol daun sirsak.

Sediaan nanopartikel alginat ekstrak etanol daun sirsak dibuat dengan cara menambahkan larutan $0,1 \%$ natrium alginat sebanyak $15 \mathrm{~mL}$ ke dalam $50 \mathrm{mg}$ ekstrak etanol daun sirsak dan dihomogenkan dengan ultrasonik probe selama 3 menit. Lalu, campuran tersebut ditambahkan secara drop by drop dengan syringe pump ke dalam $15 \mathrm{~mL} \mathrm{CaCl}_{2} 0,1 \%$ dalam waktu 10 menit sambil dihomogenkan menggunakan aerator dan ultrasonik. Larutan tersebut dihomogenkan kembali dengan stirer selama 5 menit, kemudian dilakukan pembacaan ukuran dan zeta potensial partikel menggunakan particle size analyzer (PSA). 
Uji sitotoksisitas dilakukan dengan metode tetrazolium 3-(4,5-dimetiltiazol-2-il) 2,5difeniltetrazolium bromid (MTT), kemudian absorbansi diukur menggunakan ELISA reader. Sediaan nanopartikel eksktrak daun sirsak (NPS) diuji pada konsentrasi 500; 250; 125; 62,5; 31,$25 ; 15,625 ; 7,8125 \mu \mathrm{g} / \mathrm{mL}$. Selanjutnya, dilakukan perhitungan persentase viabilitas sel menggunakan rumus:

\begin{tabular}{llll}
\hline & Absorbansi perlakuan & - & Absorbansi kontrol media \\
\cline { 2 - 4 } Persentase sel hidup $=$ & Absorbansi kontrol sel & - & Absorbansi kontrol media
\end{tabular}

Konsentrasi yang dapat menghambat pertumbuhan sel sebesar $50 \%\left(\mathrm{IC}_{50}\right)$ dihitung menggunakan analisis regresi probit dengan software SPSS.

Penelitian ini menggunakan sel HTB183 yang telah lama disimpan dan dikembangkan di Laboratorium Parasitologi Universitas Gadjah Mada. Peneliitian ini telah mendapat persetujuan dari Dewan Komite Etik Penelitian Kedokteran dan Kesehatan Universitas Islam Bandung, Indonesia, pada tanggal 27 Mei 2021 dengan Nomor etik: 070/KEPKUnisba/V/2021..

\section{Hasil Penelitian dan Pembahasan}

\section{Hasil}

Uji sitotoksik dilakukan menggunakan metode MTT pada serial konsentrasi 500; 250; 125; 62,5; 31,$25 ; 15,625 ; 7,8125 \mu \mathrm{g} / \mathrm{mL}$. Hasil uji sitotoksik menunjukkan nanopartikel alginat ekstrak etanol daun sirsak memiliki IC50 sebesar 31,261 $( \pm 4,4) \mu \mathrm{g} / \mathrm{mL}$. Hasil tersebut menunjukan bahwa sediaan nanopartikel ekstrak etanol daun sirsak memiliki efek antikanker sedang. Grafik $\mathrm{IC}_{50}$ dari nanopartikel alginat ekstrak etanol daun sirsak dapat dilihat pada Gambar 1.

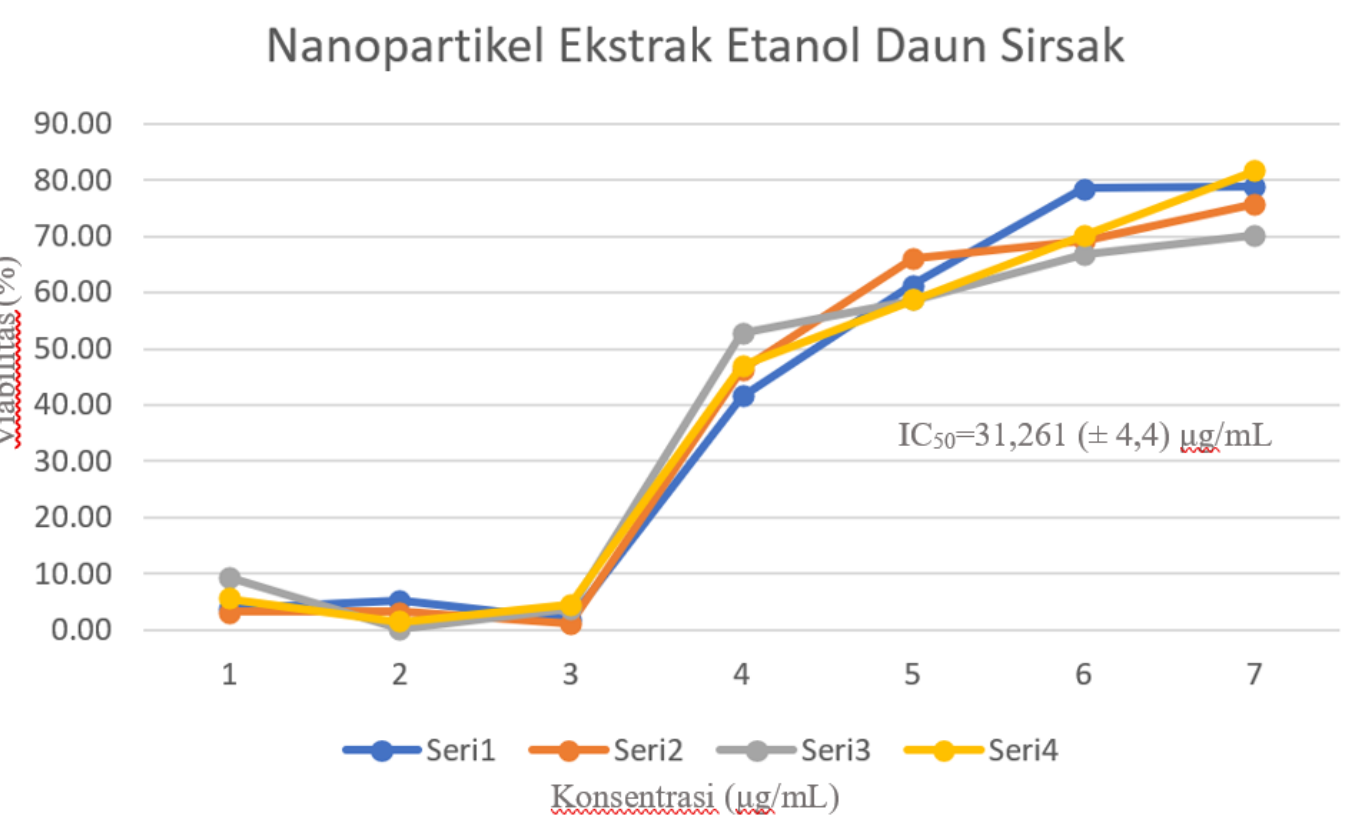

Gambar 1. Grafik Hubungan Konsentrasi Sediaan Nanopartikel Etanol Daun Sirsak dengan Viabilitas Sel. 
Sedangkan hasil viabilitas sel yang diberi senyawa nanopartikel ekstrak etanol daun sirsak pada kultur sel kanker paru HTB 183 dapat dilihat dalam Tabel 1.

Tabel 1. Efek Senyawa NPS pada Kultur Sel HTB183

\begin{tabular}{llc}
\hline Senyawa & Konsentrasi $\boldsymbol{\mu g} / \mathbf{m L}$ & Rerata Viabilitas $(\%)$ \\
\hline & 500 & 5.51 \\
& 250 & 2.51 \\
NPS & 125 & 2.85 \\
& 62,5 & 46.95 \\
& 31,25 & 61.24 \\
& 15,625 & 71.26 \\
& 7,8125 & 76.66 \\
\hline
\end{tabular}

\section{Pembahasan}

Kanker paru merupakan keganasan yang terjadi karena pertumbuhan sel yang tidak terkontrol pada jaringan paru. Kanker paru menjadi kanker paling tinggi kedua jumlah insidensinya dan menjadi kanker dengan kematian paling banyak.11 Penelitian obat antikanker terus dikembangkan untuk menghasilkan obat antikanker yang memiliki efektivitas yang tinggi dan efek samping yang rendah sehingga dapat menekan angka kejadian kanker paru.4 Salah satu strateginya dengan eksplorasi bahan, ekstrak daun sirsak menjadi salah satu bahan alam yang mengandung senyawa antikanker.6

Pada penelitian ini hasil uji sitotoksik menggunakan metode MTT menunjukkan IC50 sediaan nanopartikel alginat ekstrak etanol daun sirsak sebesar 31,261 $\mu \mathrm{g} / \mathrm{mL}$. Berdasar atas IC50 tersebut menunjukkan bahwa sediaan nanopartikel alginat ekstrak etanol daun sirsak memiliki efek toksisitas sedang berdasarkan referensi Baharum dkk.12 Penelitian ini sejalan dengan beberapa penelitian terdahulu yang mengungkapkan bahwa daun sirsak memiliki efek antikanker. Daun sirsak mengandung berbagai senyawa seperti flavonoid, annonaceous acetogeni compounds (AGEs), dan alkaloid yang memiliki kemampuan antikanker. Annonaceous acetogenin compounds memiliki kemampuan untuk menghambat mitochondrial complex I yang sehingga dapat menghambat pembentukan ATP dan mampu menginduksi apoptosis sel kanker.13 Selain itu AGEs mampu menginhibisi lactate dehydrogenase yang merupakan suatu enzim yang berfungsi sebagai antioksidan sehingga menginduksi stres oksidatif dan memicu apoptosis serta autofagi sel.14

Penelitian yang dilakukan oleh Suhendar15 menujukkan bahwa ekstrak etanol daun sirsak memiliki efek toksik terhadap sel kanker MCF-7 dengan nilai IC50 yang rendah sebesar $9.12 \mu \mathrm{g} \mathrm{mL}$. Selain itu, selaras dengan penelitian Yang dkk,16 mengenai induksi apoptosis sel ekstrak etanol Annona muricata. L terhadap kanker hati melalui jalur ROS. Uji menggunakan metode TUNEL menunjukkan bahwa ekstrak etanol daun sirsak mampu menginduksi apoptosis pada sel kanker.

Beberapa penelitian terdahulu mendukung bahwa nanopartikel memiliki peluang untuk meningkatkan efikasi suatu obat sehingga diharapkan pengolahan senyawa ekstrak etanol daun sirsak dalam bentuk nanopartikel dapat meningkatkan efektivitas obat. Sejalan dengan penelitian Cavalcanti dkk,17 mengenai nanopartikel dalam penggunaan produk alam untuk pengobatan kanker paru menunjukkan hasil penggunaan nanopartikel memiliki keunggulan stabilitas yang tinggi dan solubilisasi yang baik sehingga dapat meningkatkan natural product delivery dan meningkatkan efek terapetik terhadap sel kanker paru serta mengurangi efek samping natural product tersebut. Penelitian Gonzales Pedroza dkk,18 mengenai nanopartikel perak ekstrak kulit dan daun Annona muricata menunjukkan bahwa sedian nanopartikel kulit dan daun sirsak memiliki efek antitumor yang poten terhadap sel kanker payudara, kolon, dan melanoma. Penelitian Song dkk,19 menunjukkan kultur sel kanker payudara MDA-MB-231 yang diberi obat nanopartikel alginat/kitosin kurkumin memiliki efesiensi pengobatan $3 \square 6 \mathrm{kali}$ lipat dibanding dengan pemberian kurkumin tidak dalam bentuk nanopartikel. Keterbatasan pernelitian ini adalah uji antikanker hanya dilakukan pada satu jenis kultur sel kanker paru, yaitu 
sel HTB183 dan uji tidak dilakukan pada sel normal sehingga tidak dapat ditentukan efek toksik terhadap sel normal.

Penelitian selanjutnya diharapkan dapat dilakukan uji sediaan nanopartikel alginat ekstrak etanol daun sirsak (Annona muricata L) dan doksorubisin terhadap kultur sel kanker lain serta diuji pada sel normal juga sehingga dapat diukur efek samping yang ditimbulkan. Penelitian ini dapat dilanjutkan dengan pengujian terhadap hewan uji hinga ke tingkat klinik sehingga mampu menjadi sumbangsih untuk perkembangan obat ko-kemoterapi terutama di Indonesia.

\section{Kesimpulan}

Simpulan penelitian ini adalah nanopartikel alginat ekstrak daun sirsak (Annona muricata Linn.) bersifat antikanker sedang pada kultur sel kanker paru HTB183.

\section{Acknowledge}

Penelitian ini terselenggara berkat dukungan penuh dari Lembaga Penelitian dan Pengabdian kepada Masyarakat (LPPM) Universitas Islam Bandung yang mendukung pendanaan penelitian ini (kontrak hibah PDU nomor 100/B.04/LPPM/XII/2020). Kepada Laboratorium Parasitologi FKMK UGM, Farmasi, dan Biomedik Unisba

\section{Daftar Pustaka}

[1] Siegel RL, Miller KD, Fuchs HE, Jemal A. Cancer statistics, 2021. CA Cancer J Clin. 2021;71(1):7-33.

[2] The American Cancer Society. Lung cancer causes, risk factors, and prevention. Am Cancer Soc. 2019;1-14.

[3] Cooper WA, Lam DCL, O'Toole SA, Minna JD. Molecular biology of lung cancer. J Thorac Dis. 2013;5(SUPPL.5):703-40.

[4] Hudoyo A, Wibawanto A, Lutfi A, et al. Pedoman Nasional pelayanan kedokteran kanker paru. 2015;1-72.

[5] Duma N, Santana-Davila R, Molina JR. Non-small cell lung cancer: epidemiology, screening, diagnosis, and treatment. mayo clin proc. 2019;94(8):1623-40. doi.org/10.1016/j.mayocp.2019.01.013

[6] Moghadamtousi SZ, Rouhollahi E, Karimian H, Fadaeinasab M, Firoozinia M, Ameen Abdulla $M$, et al. The chemopotential effect of annona muricata leaves against azoxymethane-induced colonic aberrant crypt foci in rats and the apoptotic effect of acetogenin annomuricin E in HT-29 cells: a bioassay-guided approach. 2015;

[7] Nn A. A Review on the extraction methods use in medicinal plants, principle, strength and limitation. med aromat plants. 2015;04(03):3-8.

[8] Carré P, Citeau M, Dauguet S. Hot ethanol extraction: Economic feasibility of a new and green process. OCL - Oilseeds fats, Crop Lipids. 2018;25(2).

[9] Kopeckova K, Eckschlager T, Sirc J, Hobzova R, Plch J, Hrabeta J, et al. Nanodrugs used in cancer therapy. Biomed Pap. 2019;163(2):122-31.

[10] Choukaife H, Doolaanea AA, Alfatama M. Alginate nanoformulation: Influence of process and selected variables. Vol. 13, Pharmaceuticals. 2020. 1-35 p.

[11] Bade BC, Dela Cruz CS. Lung cancer 2020: epidemiology, etiology, and prevention. Clin Chest Med. 2020;41(1):1-24. doi.org/10.1016/j.ccm.2019.10.001

[12] Baharum Z, Akim AM, Taufiq-Yap YH, Hamid RA, Kasran R. In vitro antioxidant and antiproliferative activities of methanolic plant part extracts of Theobroma cacao. Molecules. 2014;19(11):18317-31.

[13] Rady I, Bloch MB, Chamcheu RCN, Banang Mbeumi S, Anwar MR, Mohamed H, et al. Anticancer properties of graviola (annona muricata): a comprehensive mechanistic review. Oxid Med Cell Longev. 2018;2018. 
[14] Jacobo-Herrera N, Pérez-Plasencia C, Castro-Torres VA, Martínez-Vázquez M, GonzálezEsquinca AR, Zentella-Dehesa A. Selective acetogenins and their potential as anticancer agents. Front Pharmacol. 2019;10(July):1-12.

[15] Suhendar U. Geographycal effect on the cytotoxic activity of annona muricata 1 . leaves ethanol extract against MCF-7 cancer cell. fitofarmaka J Ilm Farm. 2019;8(2):71-8.

[16] Yang H, Liu N, Lee S. Ethanol extract of annona muricata. 1 induces liver cancer cell apoptosis through ros pathway. Biomed Pharmacol J. 2016;9(3):919-25.

[17] Cavalcanti IDL, Santos Soares JC, Pereira da Silva WF, Gomes Silva B, Antônia de Souza I. Nanopartículas en el empleo de productos naturales para el tratamiento del cáncer de pulmón. Ars Pharm. 2019;60(3):185-92.

[18] González-Pedroza MG, Argueta-Figueroa L, García-Contreras R, Jiménez-Martínez Y, Martínez-Martínez E, Navarro-Marchal SA, et al. Silver nanoparticles from annona muricata peel and leaf extracts as a potential potent, biocompatible and low cost antitumor tool. Nanomaterials. 2021;11(5):1-17.

[19] Song W, Su X, Gregory DA, Li W, Cai Z, Zhao X. Magnetic alginate/chitosan nanoparticles for targeted delivery of curcumin into human breast cancer cells. Nanomaterials. 2018;8(11). 